\title{
Intake, efficiency, and feeding behavior characteristics of Holstein-Friesian cows of divergent Economic Breeding Index evaluated under contrasting pasture-based feeding treatments
}

\author{
M. O'Sullivan, ${ }^{1,2 *}$ P. Dillon, ${ }^{1}$ K. O'Sullivan, ${ }^{3}$ K. M. Pierce, ${ }^{2}$ N. Galvin, ${ }^{1}$ M. Egan, ${ }^{1}$ and F. Buckley ${ }^{1,2}$ \\ ${ }^{1}$ Animal \& Grassland Research and Innovation Centre, Teagasc Moorepark, Fermoy, Co. Cork, P61 C997, Ireland \\ ${ }^{2}$ School of Agriculture and Food Science, University College Dublin, Belfield, Dublin, D04 N2E5, Ireland \\ ${ }^{3}$ School of Mathematical Sciences, University College Cork, Cork, T12 XF62, Ireland
}

\section{ABSTRACT}

The objective of the current study was to explore differences in dry matter intake, intake capacity, production efficiency, energy balance, and grazing behavior, of 2 divergent genetic groups (GG) of lactating HolsteinFriesian, selected using the Irish Economic Breeding Index (EBI). The GG were evaluated across 3 spring calving pasture-based feeding treatments (FT) over 3 yr. The 2 divergent GG were (1) high EBI, representative of the top 5\% nationally (elite), and (2) EBI representative of the national average (NA). In each year 90 elite and 45 NA cows were randomly allocated to 1 of 3 FT: control, lower grass allowance, and high concentrate. Although FT did affect animal performance, there were few notable incidences of GG $\times$ FT interaction. The elite cows expressed lower daily milk yield $(-1 \mathrm{~kg})$ compared with NA. Elite cows did, however, express higher daily concentrations of milk fat $(+3.7$ $\mathrm{g} / \mathrm{kg})$ and protein $(+2.1 \mathrm{~g} / \mathrm{kg})$ compared with NA. Daily yield of milk solids and net energy of lactation $\left(\mathrm{NE}_{\mathrm{L}}\right)$ was similar for both GG. Body weight $(\mathrm{BW})$ was greater for NA $(+13 \mathrm{~kg})$ compared with elite, whereas mean body condition score was greater $(+0.14)$ for elite compared with NA. Intake did not differ significantly between GG. Intake capacity, expressed as total dry matter intake $/ 100 \mathrm{~kg}$ of $\mathrm{BW}$, was greater with elite compared with NA. Production efficiency expressed as yield of milk solids per $100 \mathrm{~kg}$ of BW was greater with elite compared with NA, although milk solids/total dry matter intake did not differ between GG. Expressed as $\mathrm{NE}_{\mathrm{L}}$ as a proportion of net energy intake minus net energy of maintenance $\left(\mathrm{NE}_{\mathrm{L}} / \mathrm{NE}_{\mathrm{I}}-\mathrm{NE}_{\mathrm{M}}\right)$ and $\mathrm{NE}_{\mathrm{I}} / \mathrm{milk}$ solids $\mathrm{kg}$, indicated a slight reduction in the utilization of ingested energy for milk production with elite compared with NA. This is, however, suggested as favorable as it manifested as a more positive energy balance with

Received January 25, 2019.

Accepted May 5, 2019.

*Corresponding author: Morgan.OSullivan@teagasc.ie elite compared with NA and so is likely to enhance robustness, increase longevity, and increase overall lifetime efficiency. Noteworthy was a consistent numerical trend toward more intense grazing activity with elite compared with NA cows, exhibited in the numerically greater grazing time $(+19 \mathrm{~min})$ and total number of bites per day $(+2,591)$.

Key words: dairy, economic breeding index, intake, efficiency

\section{INTRODUCTION}

Pasture-based dairy production in Ireland is characterized by long-term perennial ryegrass pastures and the application of grazing management practices to maximize pasture production and quality in combination with relatively high stocking density to result in high milk solids (milk solids; fat plus protein yield) production per unit area (Delaby et al., 2018). The cost-benefit advantage of pasture-based production for Irish dairy producers is clear. Total feed costs account for approximately $80 \%$ of the total variable costs associated with milk production, and profit is maximized by increasing the proportion of grazed grass in the diet of the lactating dairy cow (Shalloo et al., 2004). According to Hanrahan et al. (2018), each additional tonne of pasture DM used is associated with a $€ 173$ increase in net profit per hectare on Irish dairy farms.

Lessons from previous studies on animals selected under contrasting breeding objectives (Buckley, 1998; Kennedy et al., 2003; Horan et al., 2006) collectively highlight a clear requirement for appropriate genetic selection to ensure compatibility with pasture-based systems. Dairy cows that are optimal in a pasture-based system of production share many general characteristics with cows that are appropriate for a nonpasture system, although the relative importance of traits can differ (Washburn and Mullen, 2014). Dairy cows appropriate to grazing systems must display an innate capability to achieve large intakes of grazed pasture, sufficient to meet energetic requirements (Buckley et al., 2005), thus 
enabling high output (in Ireland equating to high milk fat plus protein yield) in a manner that is sustainable as signified by energy balance (EB) and production efficiency (PE). Furthermore, cows must demonstrate a compatibility or robustness to the environment given the challenges posed by grazing: energy expenditure associated with grazing activity (Dohme-Meier et al., 2014), variability in seasonal weather conditions, and a fluctuating feed supply both in terms of availability and quality (Bargo et al., 2003; Van Vuuren and Van den Pol-van Dasselaar, 2006).

Because grazing systems represent a minority of global milk production (Steinfeld and Mäki-Hokkonen, 1995), the majority of dairy cattle have not been selected under grazing conditions. Previous research demonstrated that selection for high production potential resulted in dairy cows with high genetic merit for milk production (Evans et al., 2006); however, such animals were not capable of consuming enough to satisfy their energetic demands from pasture (Kennedy et al., 2003; Horan et al., 2006). Although evolvement toward selection for multiple traits in selection indexes globally is evident (Miglior et al., 2017) selection for production traits retains considerable emphasis in the selection indexes of many milk-producing countries (Miglior et al., 2012; Washburn and Mullen, 2014). Notwithstanding progress in countries such as Australia (Pryce et al., 2015) and the Netherlands (Manzanilla-Pech et al., 2017), direct selection for grazing aptitude, feed intake, and feed efficiency in dairy indexes has been limited. This has been primarily due to a lack of appropriate data upon which to base selection (Ngwerume and Mao, 1992; Berry and Crowley, 2013).

Selection of Irish dairy cattle is based on total merit using the Economic Breeding Index (EBI; Veerkamp et al., 2002). The EBI weights productivity, fertility, and survival, and a range of management-oriented traits in the context of profitable seasonal pasture-based dairy production (www.ICBF.com). The positive effect of EBI on milk production performance has been reported by O'Sullivan et al. (2019). The current study explores differences in DMI, intake capacity, production efficiency, EB, and grazing aptitude between 2 genetic groups of HF. The objective was to validate the true compatibility of animals selected on EBI with contrasting pasture-based management scenarios reflective of the upper and lower limits of recommended best practice to maximize productivity in Irish milk production systems (O'Donovan et al., 2011).

\section{MATERIALS AND METHODS}

The present study was undertaken at the Dairygold Research Farm (Teagasc, Animal and Grassland Re- search and Innovation Centre, Moorepark, Fermoy, Co. Cork, Ireland; $52^{\circ} 09^{\prime} \mathrm{N} ; 8^{\circ} 16^{\prime} \mathrm{W}$ ), over a 3 -yr period (2014-2016). It formed part of a larger study established to validate the phenotypic and financial performance of dairy cows selected using the Irish EBI, across contrasting pasture-based feeding treatments.

A detailed outline of the study design has been provided by O'Sullivan et al. (2019). Briefly, 90 high EBI Holstein-Friesian (HF) cows (elite; within the top 5 percentile of cows nationally, ranked on EBI), and 45 national average EBI cows (NA; representative of national average genetic merit based on EBI) were included in each year of this 3-yr study (2014-2016). Across the 3 experimental years, the mean EBI, milk, fertility, calving, beef, maintenance, and health subindex (SD in parentheses) of the elite and NA genetic group (GG), excluding both own and progeny performance, was $€ 160$ (34.2), €30 (20.0), €107 (28.7), €31 (8.0), $-€ 21$ (10.0), €13 (8.4), and €0 (4.6), and €52 (33.2), €8 (18.2), €30 (24.6), €25 (9.0), -€13 (8.2), $€ 3$ (8.8), and $-€ 1$ (4.5), respectively (ICBF, January 2018). Mean calving date was February 17 ( \pm 16 d) in the elite, and February $20( \pm 18 \mathrm{~d})$ in the NA over the 3 -yr study period.

\section{Grazing Management and Feeding Treatments}

Cows within each GG were randomly assigned each year postpartum to 1 of 3 pasture-based experimental feeding treatments (FT) in mid-March, and mid-April, for the early and later calving cows, respectively. Randomization was performed on the basis of EBI, parity, calving date, and pre-experimental (mean of $2 \mathrm{wk}$ ) yield of milk solids ( $\mathrm{kg}$ of fat plus protein), being mindful to arrive at similar treatment averages for BW, BCS, milk yield (MY), and fat and protein content. Experimental treatments were control (CTL), lower grass allowance (LGA), and high concentrate (HC), with target postgrazing compressed sward heights of 4.5 to $5,3.5$ to 4 , and 4.5 to $5 \mathrm{~cm}$, and a planned total lactation concentrate allowance of 300,300 , and $1,100 \mathrm{~kg}$ per cow per lactation, respectively. Elite and NA cows within each FT were grazed separately in adjacent paddocks.

\section{Milk Production, BW, and BCS}

Cows were milked twice daily at 0700 and $1530 \mathrm{~h}$ throughout lactation. Individual cow MY in kilograms was recorded daily using electronic milk meters (Dairymaster, Causeway, Co. Kerry, Ireland). Milk fat, protein, and lactose concentrations were determined weekly from one successive p.m. and a.m. milk sample using a Milkoscan FT6000 (Foss Electric, Hillerød, Denmark). Body weight of each animal was recorded weekly using 
a calibrated electronic scale (Dairymaster). Body condition score was recorded every 2 wk in early lactation (up to wk 10 of lactation), and approximately every 3 to 4 wk thereafter throughout the study by a single evaluator, on a scale of 1 to 5 (with 1 being extremely thin and 5 being extremely fat), with increments of 0.25 , similar to the scoring described by Lowman et al. (1976).

\section{DMI, Efficiency, and Grazing Behavior}

Individual cow DMI was estimated using the $n$-alkane technique (Mayes et al., 1986) as modified by Dillon and Stakelum. (1989) on 4 occasions during the grazing season in 2014 (early May, mid June, mid August, and mid October), on 3 occasions during the grazing season in 2015 (early May, late June, and mid September), and on 4 occasions during the grazing season in 2016 (early May, mid July, early August, and early October). During each of the intake measurement periods, the diet consisted of pasture plus $0.2 \mathrm{~kg}$ of concentrate in the CTL and LGA treatments, and pasture plus $4-\mathrm{kg}$ concentrate supplementation in the HC. The intake measurements were classified into periods: measurement period 1 corresponded to all intake measurements conducted in May (late spring), measurement period 2 corresponded to intake measurements conducted during June and July (summer), and measurement period 3 corresponded to all intake measurements carried out during August, September and October (autumn). Observations of individual cow daily grass DMI (GDMI) and total DMI (TDMI; grass plus concentrate) corresponded to an average of 90, 127, and 218 DIM for measurement period 1, 2, and 3, respectively. Individual observations of cow DMI corresponded to a range of 27 to 279 DIM. Mean substitution rate of grass for concentrate was calculated as per Bargo et al. (2003). In total, 1,463 DMI records (970 elite and $463 \mathrm{NA}$, respectively) were available from 227 individual cows (145 elite and $82 \mathrm{NA}$, respectively) over the $3 \mathrm{yr}$.

Estimates of intake capacity (TDMI/100 kg of BW), and production efficiencies expressed as the ratio of milk solids to TDMI (milk solids/TDMI), milk solids per unit of $\mathrm{BW}$ (milk solids/100 $\mathrm{kg}$ of $\mathrm{BW}$ ), $\mathrm{NE}_{\mathrm{L}} /$ net energy intake $\left(\mathrm{NE}_{\mathrm{I}}\right)-\mathrm{NE}_{\mathrm{M}}\left(\mathrm{NE}_{\mathrm{L}} / \mathrm{NE}_{\mathrm{I}}-\mathrm{NE}_{\mathrm{M}}\right)$ representing the proportion of energy available for milk production having accounted for maintenance, and $\mathrm{NE}_{\mathrm{I}} /$ milk solids $\mathrm{kg}$, denoting the energy required to produce $1 \mathrm{~kg}$ of milk solids, were derived as described by Prendiville et al. (2009). Energetic calculations were based on daily milk production, BW, and estimated TDMI during the intake measurement periods using the net energy system (Jarrige, 1989), where 1 unité fourragère lait (UFL) of energy is defined as the net energy content of $1 \mathrm{~kg}$ of standard barley for milk production, equivalent to 1,700 kcal. Energy balance for individual animals was calculated as the difference between estimated energy requirement and estimated total energy intake as described by Horan et al. (2006).

Grazing behavior was recorded on 2 occasions during the 2016 grazing season during June 17 to July 21 (period 1) and from August 4 to September 8 (period 2). These periods corresponded to 139 and 195 DIM, respectively. After morning milking, cows were fitted with RumiWatchSystem (Itin + Hoch GmbH, Liestal Switzerland) halters, a grazing behavior recording device, validated by Werner et al. (2018). In preparation, cows were fitted with head collars minus the Rumiwatch device $24 \mathrm{~h}$ earlier. Grazing behavior was recorded over a 6-d period, thus capturing the expression of natural grazing behavior for the duration of a partial grazing rotation. Recordings started at $0900 \mathrm{~h}$. Sunrise and sunset was 0512 and $2157 \mathrm{~h}$, and 0538 and $2141 \mathrm{~h}$, respectively, at the start and at the end of recording period 1. Sunrise and sunset was 0600 and $2117 \mathrm{~h}$, and 0655 and $2005 \mathrm{~h}$, respectively, at the start and end of recording period 2. Diurnal patterns of grazing behavior were established by classifying the daily recording hours into day and night periods based on sunrise and sunset times during both recording periods.

Grazing behavior was recorded on up to a maximum of 41 cows per week during measurement period 1 , and a maximum of 36 cows per week during measurement period 2. A total of 140 and 149 attempts yielded 129 and 129 individual cow records from grazing behavior measurement periods 1 and 2, respectively. Failed attempts were associated with difficulties downloading the recorded data from the storage device $(36 \%)$, incorrect fitting of the devices to cows $(34 \%)$, or failure to correctly start the device $(30 \%)$. The Rumiwatch halter was removed from cows after morning milking at the end of each recording period and the automatically captured data were collated following the same procedure as Werner et al. (2018). Data were analyzed using SAS (SAS Institute Inc., 2017). A total of 258 grazing and ruminating behavior records (172 elite and 86 NA, respectively) from 129 cows (86 elite and 43 NA, respectively) from 1 yr (2016) were included in the analysis.

\section{Sward Measurements}

Pre- and postgrazing compressed sward height, and pregrazing herbage mass (above $4 \mathrm{~cm}$ horizon) was determined before grazing on each paddock selected for grazing during the intake measurement periods, as outlined by O'Sullivan et al. (2019). The average paddock pregrazing herbage mass and daily herbage allowance 
(DHA) above a cutting height of $4 \mathrm{~cm}$ was calculated using the measurements below:

Pregrazing herbage mass $(\mathrm{kg}$ of $\mathrm{DM} / \mathrm{ha})=$ [pregrazing compressed sward height $(\mathrm{mm})-40 \mathrm{~mm}$ ] $\times$ sward density $(\mathrm{kg}$ of $\mathrm{DM} / \mathrm{mm}$ per ha),

where average DHA = pregrazing herbage mass, $\mathrm{kg}$ of $\mathrm{DM} /$ ha $\times$ daily grazing area allowance (ha/cow).

During each intake measurement period, herbage samples representing pasture selected by the cows were collected manually in each paddock before grazing using a Gardena hand shears (Accu 60, Gardena International GmbH, Ulm, Germany) on d 6 to 11 to facilitate analysis of the herbage by the $n$-alkane technique (Mayes et al., 1986). The ratio of herbage C33-alkane (tritriacontane) to dosed C32-alkane was used to estimate DMI. A sub-sample of the herbage sampled from each paddock was freeze-dried and used for chemical analysis.

\section{Chemical Analysis}

Composite samples of both offered and selected herbage were analyzed in vitro for ADF, CP (Leco FP-428; Leco Australia Pty Ltd., Baulkham Hills, New South Wales, Australia), NDF (Ankom technology, Macedon, NY; Van Soest et al., 1991), organic matter digestibility (Fibertec Systems, Foss, Ballymount, Dublin, Ireland; Morgan et al., 1989), DM, and ash. Concentrate samples were collected weekly and analyzed using near infrared reflectance spectroscopy (Foss-NIR System DK, Hillerød, Denmark) for DM, ash, CP, NDF, and crude fiber. During the winter period a composite sample of grass silage was analyzed for DM, pH, ash, CP, DMD, and NDF.

\section{Statistical Analysis}

Sward Measurements. The effects of GG, FT, year, and measurement period on pregrazing herbage mass, pregazing compressed sward height, postgrazing compressed sward height, DHA, and chemical composition of the herbage offered during the intake measurement periods were analyzed using mixed models (PROC MIXED, SAS Institute Inc., 2017). The initial model comprised the fixed effects of GG, FT, year, and their interactions, with measurement period included as a repeated effect. Paddock was included as the random effect. The denominator degrees of freedom were adjusted using the method of Kenward-Roger (Chapa et al., 1995) and each model was tested using 4 dif- ferent covariance structures (autoregressive order one, autoregressive order one with heterogeneous variance, compound symmetry, and unstructured). The model and covariance structure with the lowest Akaike's information criterion determined the most appropriate residual covariance structure for repeated measures. A compound symmetry error structure was subsequently determined as the most appropriate residual covariance structure for repeated measures. Interactions that were nonsignificant were eliminated from the model by backward elimination. The final model was

$$
\mathrm{R}_{i j k l}=\mu+\mathrm{Y}_{i}+\mathrm{G}_{j}+\mathrm{F}_{k}+\mathrm{M}_{l}+\mathrm{e}_{i j k l},
$$

where $\mathrm{R}_{i j k l}=$ the observation for the dependent variable (pregrazing herbage mass, pregazing compressed sward height, postgrazing compressed sward height, DHA, and chemical composition of the herbage); $\mathrm{Y}_{i}=$ the effect of $i$ th year $(i=1,2,3,4) ; \mathrm{G}_{j}=$ the effect of the $j$ th genetic group $(j=$ elite, $\mathrm{NA}) ; \mathrm{F}_{k}=$ the effect of the $k$ th feeding treatment $(k=\mathrm{CTL}, \mathrm{HC}, \mathrm{LGA}) ; \mathrm{M}_{l}=$ the effect of $l$ th measurement period $(l=1,2,3)$; and $\mathrm{e}_{i j k l}$ $=$ the residual error term.

Milk Production, DMI, and Efficiency. The effect of GG and FT on daily MY, milk fat and protein content, yield of milk solids per cow, total DMI per cow and measures of DMI and PE were determined. Cow nested within GG was treated as the random effect and the model was adjusted for calving day of year. Measurement period by year was treated as the repeated effect. Initial models included the effects of GG, FT, year, parity, measurement period and their interactions. Effects that were nonsignificant $(P>$ $0.05)$ were eliminated from the model. The final model consisted of the main effects of GG and FT, adjusted for calving day of year and measurement period. The denominator degrees of freedom were adjusted using the method of Kenward-Roger (Chapa et al., 1995). Using the Akaike's information criterion a compound symmetry error structure was determined as the most appropriate residual covariance structure for repeated measures within cows. The final model used was

$$
\mathrm{R}_{i j k l p}=\mu+\mathrm{Y}_{i}+\mathrm{L}_{j}+\mathrm{G}_{k}+\mathrm{F}_{l}+\mathrm{M}_{p}+\mathrm{e}_{i j k l p},
$$

where $\mathrm{R}_{i j k l p}=$ the performance of the animal in year $i$, of parity $j$, and genetic group $k$, on feeding treatment $l$, in measurement period $p ; \mathrm{Y}_{i}=$ the effect of the $i$ th year $(i=1,2,3) ; \mathrm{L}_{j}=$ parity $(j=2,3,4), \mathrm{G}_{k}=$ genetic group of $\mathrm{HF}(k=$ elite, $\mathrm{NA}) ; \mathrm{F}_{l}=$ the effect of the $l$ th feeding treatment $(l=\mathrm{CTL}, \mathrm{HC}, \mathrm{LGA}) ; \mathrm{M}_{p}=$ the effect of measurement period $(p=1,2,3)$, and $\mathrm{e}_{i j k l p}=$ the residual error term. 
Grazing and Ruminating Behavior. Genetic group, FT, and parity were treated as fixed effects. Cow nested within GG was treated as the random effect. Measurement period was treated as the repeated effect. Using the Akaike's information criterion, a compound symmetry covariance structure provided the best fit to the data. With the exception of the interaction of GG and FT, interactions that were nonsignificant $(P>$ $0.05)$ were eliminated from the final model. The final model was

$$
\mathrm{R}_{i j k l}=\mu+\mathrm{L}_{i}+\mathrm{G}_{j}+\mathrm{F}_{k}+\mathrm{M}_{l}+\mathrm{e}_{i j k l}
$$

where $\mathrm{R}_{i j k l}=$ the feeding behavior of the animal of parity $i$, and genetic group $j$, on feeding treatment $k ; \mathrm{L}_{i}$ $=$ parity $(i=2,3,4), \mathrm{G}_{j}=$ genetic group of $\operatorname{HF}(j=$ elite, NA); $\mathrm{F}_{k}=$ the effect of the $k$ th feeding treatment ( $k=\mathrm{CTL}, \mathrm{HC}, \mathrm{LGA}) ; \mathrm{M}_{l}=$ the effect of measurement period $(l=1,2)$, and $\mathrm{e}_{i j k l}=$ the residual error term.

\section{RESULTS}

\section{Pasture Availability and Quality}

The effect of GG and FT on pregrazing herbage yields, pregrazing and postgrazing compressed sward heights, and DHA during the intake measurement periods of the current study are summarized in Table 1 . Pregrazing herbage yields and pregrazing compressed sward heights did not differ significantly between GG in any of the $3 \mathrm{FT}$. Postgrazing compressed sward heights differed between FT, in line with the study objective. No difference was observed in herbage allowance between GG. The CTL received a greater herbage allowance than the $\mathrm{HC}$ and LGA during each of the intake measurement periods. The chemical analysis of the herbage representing that selected by the cows is presented in Table 2. The chemical composition did not differ between GG in any of the 3 FT. The chemical composition of pasture offered during the current study was consistent between elite and NA, across each of the $3 \mathrm{FT}$, and was consistent with the nutritional value of offered herbage previously reported by O'Sullivan et al. (2019), and so therefore is not presented.

\section{Milk Production and Composition}

The effect of GG and FT on mean daily milk production performance across the intake measurement periods is presented in Table 3. No significant interaction between GG and FT was observed for any of the milk production traits investigated. There was a significant effect of GG on daily MY, fat concentration, and protein concentration. The NA cows had greater $(P<$
$0.001)$ daily MY $(22.1 \mathrm{~kg} / \mathrm{d})$ compared with elite $(21.2$ $\mathrm{kg} / \mathrm{d})$. The elite cows had greater $(P<0.001)$ daily concentrations of milk fat and milk protein compared with NA (+3.7 and $2.1 \mathrm{~g} / \mathrm{kg}$, respectively). Lactose concentration, daily yield of milk solids, and $\mathrm{NE}_{\mathrm{L}}$ did not differ significantly between GG.

A significant effect was observed of FT $(P<0.001)$ on all milk production variables measured. Cows on the $\mathrm{HC}$ treatment produced higher daily MY $(24.6 \mathrm{~kg} / \mathrm{d})$ and daily milk solids yield $(1.89 \mathrm{~kg} / \mathrm{d})$, compared with CTL (20.8 and $1.63 \mathrm{~kg}$, respectively). The LGA produced lower MY and milk solids yield (19.7 and 1.53 $\mathrm{kg}$, respectively) compared with CTL. Milk protein and lactose concentrations were greater in the HC (37.4 and $48.3 \mathrm{~g} / \mathrm{kg}$ ) compared with CTL (37.1 and $47.8 \mathrm{~g} / \mathrm{kg}$ ). Milk protein and lactose concentrations were lower in the LGA (36.4 and $47.7 \mathrm{~g} / \mathrm{kg}$ ) compared with CTL. Milk fat concentration was lowest in the HC (40.8 g/ $\mathrm{kg}$ ) compared with CTL $(42.2 \mathrm{~g} / \mathrm{kg})$. Milk fat was highest with LGA $(42.7 \mathrm{~g} / \mathrm{kg})$ compared with CTL. The $\mathrm{NE}_{\mathrm{L}}$ was higher $(P<0.001)$ in the $\mathrm{HC}(11.13 \mathrm{UFL})$ compared with CTL (9.54 UFL), and lower $(P<0.001)$ in the LGA (9.02 UFL) compared with CTL.

\section{$B W$ and $B C S$}

Elite cows were lighter $(-13 \mathrm{~kg} ; P<0.01)$ compared with NA (Table 3$)$. Mean BCS was higher $(+0.14 ; P<$ $0.001)$ for elite compared with NA. Concentrate supplementation resulted in a significant increase in $\mathrm{BW}(+25$ $\mathrm{kg} ; P<0.01)$ and BCS $(+0.10 ; P<0.001)$ for HC relative to the CTL, whereas the LGA displayed a similar BW and lower $(P<0.01)$ BCS $(-0.05)$ compared with the CTL.

\section{Intake, Efficiency, and Energy Balance}

Intake expressed as both GDMI and TDMI (Table 4) did not differ between elite (15.8 and $17.1 \mathrm{~kg})$ and NA $(15.6$ and $16.9 \mathrm{~kg})$, respectively. There was no significant difference in the consequent mean daily energy intake of elite (18.01 UFL) and NA (17.85 UFL). Intake capacity expressed as TDMI/100 kg of BW was higher $(P<0.01)$ with elite cows $(3.22 \mathrm{~kg})$ compared with NA $(3.10 \mathrm{~kg})$. Yield of milk solids per $100 \mathrm{~kg}$ of BW was higher $(P<0.001)$ with elite $(0.32 \mathrm{~kg} / 100 \mathrm{~kg}$ of BW) compared with NA (0.31 kg of milk solids $/ 100 \mathrm{~kg}$ of BW). However, PE expressed as milk solids/TDMI did not differ significantly between GG. Energetic efficiency expressed as $\mathrm{NE}_{\mathrm{L}} / \mathrm{NE}_{\mathrm{I}}-\mathrm{NE}_{\mathrm{M}}$ was greater for NA (0.83) compared with elite (0.81), approaching significance $(P=0.07)$. Estimated EB was higher $(P$ $<0.05)$ with elite (2.62 UFL) compared with NA $(2.36$ UFL). 
INTAKE, EFFICIENCY, AND FEEDING BEHAVIOR CHARACTERISTICS

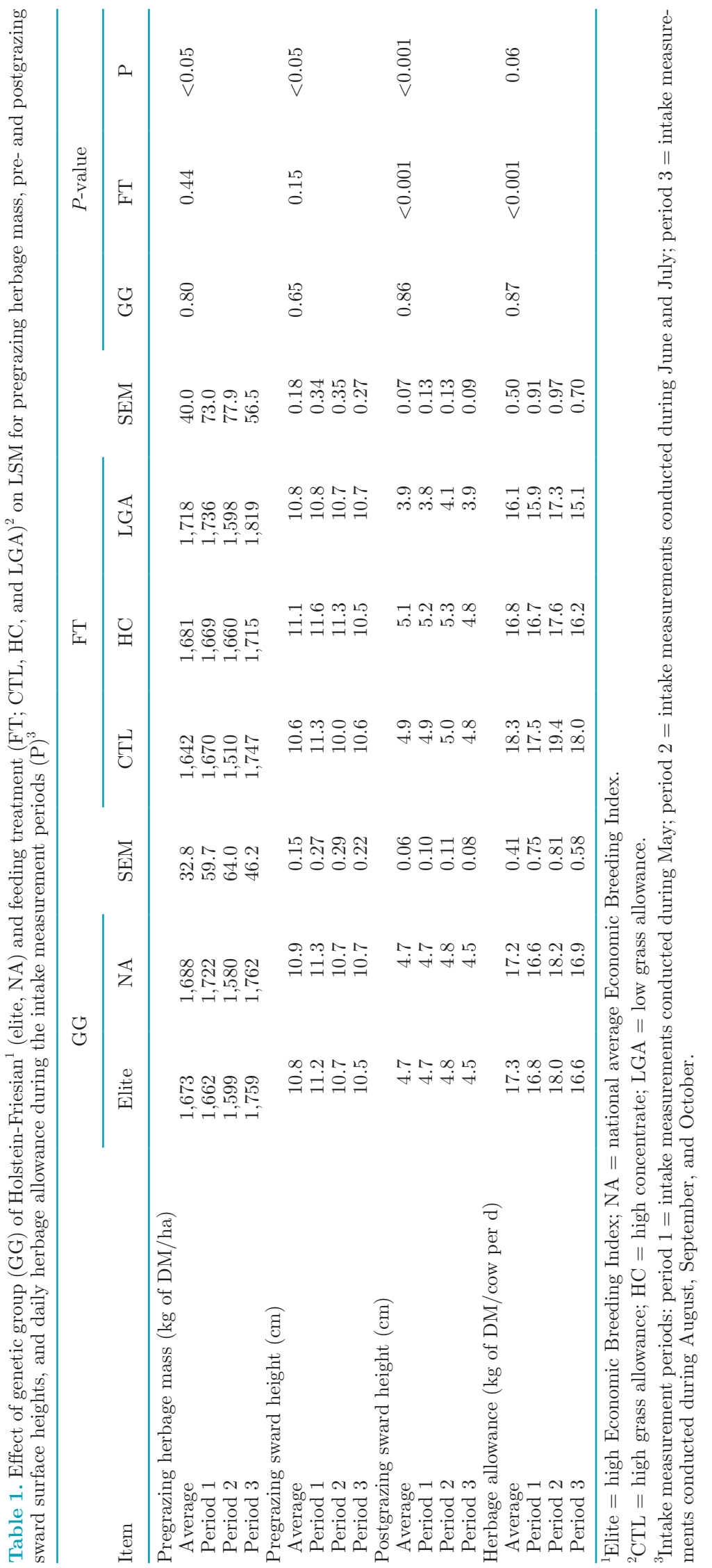


Table 2. Effect of genetic group (GG) of Holstein-Friesian (elite, NA) ${ }^{1}$ and feeding treatment (FT; CTL, HC, and LGA) ${ }^{2}$ on LSM for chemical composition of herbage sampled to represent that selected by the cows during the intake measurement periods $(\mathrm{P})^{3}$

\begin{tabular}{|c|c|c|c|c|c|c|c|c|c|c|}
\hline \multirow[b]{2}{*}{ Item } & \multicolumn{2}{|c|}{ GG } & \multirow[b]{2}{*}{ SEM } & \multicolumn{3}{|c|}{ FT } & \multirow[b]{2}{*}{ SEM } & \multicolumn{3}{|c|}{$P$-value } \\
\hline & Elite & NA & & CTL & $\mathrm{HC}$ & LGA & & GG & FT & $\mathrm{P}$ \\
\hline \multicolumn{11}{|c|}{ OM digestibility (g/kg) } \\
\hline Average & 855 & 853 & 1.50 & 856 & 855 & 851 & 1.84 & \multirow[t]{4}{*}{0.31} & \multirow[t]{4}{*}{0.15} & \multirow[t]{4}{*}{$<0.001$} \\
\hline Period 1 & 861 & 863 & 2.75 & 861 & 862 & 863 & 3.41 & & & \\
\hline Period 2 & 861 & 855 & 2.80 & 863 & 858 & 854 & 3.60 & & & \\
\hline Period 3 & 843 & 841 & 2.20 & 844 & 847 & 836 & 2.83 & & & \\
\hline Period 1 & 207 & 200 & 6.20 & 206 & 210 & 195 & 7.50 & \multirow{3}{*}{0.74} & \multirow{4}{*}{0.33} & \multirow{3}{*}{$<0.001$} \\
\hline Period 2 & 197 & 197 & 6.13 & 199 & 197 & 197 & 7.51 & & & \\
\hline Period 3 & 218 & 220 & 5.10 & 212 & 227 & 219 & 6.22 & & & \\
\hline \multicolumn{10}{|c|}{ NDF $(\mathrm{g} / \mathrm{kg})$} & \\
\hline Average & 337 & 335 & 2.56 & 335 & 335 & 337 & 3.15 & \multirow[t]{3}{*}{0.54} & \multirow[t]{3}{*}{0.82} & \multirow[t]{3}{*}{$<0.001$} \\
\hline Period 1 & 332 & 325 & 4.87 & 325 & 331 & 330 & 5.96 & & & \\
\hline Period 2 & 326 & 327 & 4.67 & 328 & 324 & 328 & 5.63 & & & \\
\hline Period 3 & 87 & 86 & 1.49 & 87 & 87 & 84 & 1.82 & 0.73 & 0.94 & $<0.001$ \\
\hline \multicolumn{11}{|c|}{$\mathrm{ADF}(\mathrm{g} / \mathrm{kg})$} \\
\hline Average & 195 & 196 & 2.17 & 193 & 196 & 196 & 2.68 & \multirow[t]{4}{*}{0.70} & \multirow[t]{4}{*}{0.58} & \multirow[t]{4}{*}{$<0.001$} \\
\hline Period 1 & 184 & 181 & 4.34 & 183 & 184 & 180 & 5.35 & & & \\
\hline Period 2 & 189 & 194 & 3.76 & 188 & 192 & 194 & 4.60 & & & \\
\hline Period 3 & 211 & 213 & 3.09 & 208 & 212 & 215 & 3.77 & & & \\
\hline
\end{tabular}

${ }^{1}$ Elite $=$ high Economic Breeding Index; NA = national average Economic Breeding Index.

${ }^{2} \mathrm{CTL}=$ high grass allowance; $\mathrm{HC}=$ high concentrate; LGA $=$ low grass allowance.

${ }^{3}$ Intake measurement periods: period $1=$ intake measurements conducted during May; period $2=$ intake measurements conducted during June and July; period $3=$ intake measurements conducted during August, September, and October.

Cows on the CTL FT achieved a higher $(P<0.001)$ daily GDMI $(16.8 \mathrm{~kg})$ than cows on both the LGA $(15.2$ $\mathrm{kg})$ and $\mathrm{HC}(15.2 \mathrm{~kg})$, consistent with DHA for each FT. Concentrate supplementation in the HC resulted in a significant increase $(P<0.001)$ in TDMI $(18.7$ $\mathrm{kg} / \mathrm{d})$ relative to CTL $(16.9 \mathrm{~kg} / \mathrm{d})$. The cows in the $\mathrm{HC}$ achieved the highest $(P<0.001)$ total daily energy intake (19.63 UFL) compared with the CTL (17.91 UFL). The lowest total daily energy intake (16.25 UFL) was observed in LGA. The $\mathrm{NE}_{\mathrm{L}} / \mathrm{NE}_{\mathrm{I}}-\mathrm{NE}_{\mathrm{M}}$ differed significantly by FT. The $\mathrm{NE}_{\mathrm{L}} / \mathrm{NE}_{\mathrm{I}}-\mathrm{NE}_{\mathrm{M}}$ was greatest $(P<0.01)$ for cows on LGA $(0.85)$ and lowest $(P<$ 0.001 ) for cows on CTL (0.79), whereas cows on HC were intermediate (0.81). Although not statistically different, the highest estimated EB was achieved by the CTL (2.95 UFL) compared with HC (2.79 UFL). Energy balance was lowest $(P<0.001)$ with LGA $(1.73$ UFL) compared with CTL. Substitution of grass for

Table 3. Effect of genetic group (GG) of Holstein-Friesian (elite, NA) ${ }^{1}$ and feeding treatment (FT; CTL, HC, and LGA) ${ }^{2}$ on LSM for milk production, lactation energy, BW, and BCS across the intake measurements

\begin{tabular}{|c|c|c|c|c|c|c|c|c|c|}
\hline Item & \multicolumn{2}{|c|}{ GG } & SEM & \multicolumn{3}{|c|}{ FT } & SEM & \multicolumn{2}{|c|}{$P$-value } \\
\hline Milk yield (kg) & 21.2 & 22.2 & 0.23 & 20.8 & 24.6 & 19.7 & 0.22 & $<0.001$ & $<0.001$ \\
\hline Protein $(\mathrm{g} / \mathrm{kg})$ & 38.0 & 35.9 & 0.19 & 37.1 & 3.74 & 36.4 & 0.18 & $<0.001$ & $<0.001$ \\
\hline Milk solids (kg) & 1.70 & 1.67 & 0.01 & 1.63 & 1.89 & 1.54 & 0.01 & 0.18 & $<0.001$ \\
\hline $\mathrm{NE}_{\mathrm{L}}\left(\mathrm{UFL}^{3}\right)$ & 9.90 & 9.89 & 0.85 & 9.54 & 11.13 & 9.02 & 0.85 & 0.97 & $<0.001$ \\
\hline
\end{tabular}

${ }^{1}$ Elite $=$ high Economic Breeding Index; NA = national average Economic Breeding Index.

${ }^{2} \mathrm{CTL}=$ high grass allowance; $\mathrm{HC}=$ high concentrate; LGA = low grass allowance.

${ }^{3}$ One unité fourragère lait is defined as the net energy content of $1 \mathrm{~kg}$ of standard barley for milk production (O'Mara, 2000). 
Table 4. Effect of genetic group (GG) of Holstein-Friesian (elite, NA) ${ }^{1}$ and feeding treatment (FT; CTL, HC, and LGA) ${ }^{2}$ on LSM for intake, efficiency, and energy balance across the intake measurements

\begin{tabular}{|c|c|c|c|c|c|c|c|c|c|}
\hline \multirow[b]{2}{*}{ Item $^{3}$} & \multicolumn{2}{|c|}{ GG } & \multirow[b]{2}{*}{ SEM } & \multicolumn{3}{|c|}{ FT } & \multirow[b]{2}{*}{ SEM } & \multicolumn{2}{|c|}{$P$-value } \\
\hline & Elite & NA & & CTL & $\mathrm{HC}$ & LGA & & GG & FT \\
\hline TDMI (kg) & 17.1 & 16.9 & 0.1 & 16.9 & 18.7 & 15.4 & 0.1 & 0.33 & $<0.001$ \\
\hline TDMI/100 kg of BW (kg) & 3.22 & 3.10 & 0.02 & 3.20 & 3.40 & 2.90 & 0.02 & $<0.01$ & $<0.001$ \\
\hline Milk solids $/ 100 \mathrm{~kg}$ of $\mathrm{BW}(\mathrm{kg})$ & 0.32 & 0.31 & 0.03 & 0.31 & 0.35 & 0.29 & 0.03 & $<0.001$ & $<0.001$ \\
\hline Milk solids/TDMI $(\mathrm{kg})$ & 0.100 & 0.099 & 0.007 & 0.097 & 0.102 & 0.100 & 0.076 & 0.41 & $<0.001$ \\
\hline Daily energy balance (UFL) & 2.62 & 2.36 & 0.87 & 2.95 & 2.79 & 1.73 & 0.99 & $<0.05$ & $<0.001$ \\
\hline
\end{tabular}

${ }^{1}$ Elite $=$ high Economic Breeding Index; NA = national average Economic Breeding Index.

${ }^{2} \mathrm{CTL}=$ high grass allowance; $\mathrm{HC}=$ high concentrate; LGA $=$ low grass allowance.

${ }^{3} \mathrm{GDMI}=$ individual cow daily grass DMI; TDMI = total DMI. One unité fourragère lait (UFL) is defined as the net energy content of 1 kg of standard barley for milk production (O'Mara, 2000). $\mathrm{NE}_{\mathrm{I}}=$ net energy intake.

concentrate did not differ between elite and NA cows during any of the intake measurement periods. Mean substitution rate of grass for concentrate was $0.49 \mathrm{~kg}$ of GDMI for each additional $\mathrm{kg}$ of concentrate intake in both the elite and NA. Mean substitution rate was lowest in spring $(0.28 \mathrm{~kg})$, highest in summer $(0.71 \mathrm{~kg})$, and intermediate in autumn $(0.48 \mathrm{~kg})$.

\section{Grazing and Ruminating Behavior}

Grazing time, number of grazing bouts, grazing bout duration, total number of bites per day, and bite rate were similar for the elite and NA cows (Table 5). Ruminating time, number of ruminating bouts, and ruminating bouts, although numerically higher, did not differ between elite and NA (Table 6). Both the number of ruminating mastications per day $(P=0.07)$, ruminating mastication rate $(P=0.09)$, and ruminating time per bolus $(P=0.06)$ tended to be higher with elite. Ruminating mastications per bolus was significantly higher $(P<0.01)$ for elite compared with NA cows.

Feeding treatment had a significant effect on the number of grazing bouts $(P<0.001)$ and the duration of grazing bouts $(P<0.001)$. A greater number of grazing bouts $(P<0.001)$ was observed for cows in the HC (10.4) compared with the CTL (8.8). Grazing bout duration expressed in minutes was shortest $(P<$ 0.001) in the HC (68.2) compared with CTL (84.3). A GG $\times$ FT interaction was observed for the number of grazing mastications $(P<0.001)$ and grazing mastication rate $(P<0.001)$. Elite cows in the CTL displayed a greater $(P<0.01)$ number of grazing mastications $(8,820)$ and a greater $(P<0.05)$ grazing mastication rate (6.1 mastications per minute) than NA cows in the CTL (6,474 and 4.5 mastications per minute, respectively). Elite cows in the LGA displayed a tendency $(P=0.06)$ for greater number of grazing mastications than NA cows in the LGA; however, grazing mastication rate did not differ. No difference was observed in the number of grazing mastications and rate of grazing mastication for elite and NA cows within the HC. Ruminating behavior did not differ across FT. No GG $\times$ FT interactions were evident in any of the recorded ruminating measurements.

Diurnal patterns of grazing did not differ between elite and NA. The greatest proportion of time spent grazing occurred during the daytime for both elite and NA (69.6 and $70.6 \%$, respectively). Elite cows displayed numerically higher daytime and night time grazing times than NA during period 1 and period 2 .

\section{DISCUSSION}

The pasture measurements in the current study demonstrate a high level of grazing management and technical efficiency, comparable with similar studies conducted at the same research center (McCarthy et al., 2007; Prendiville et al., 2009). Critically, pasture quality was consistent across all $3 \mathrm{FT}$ and differed only in quantity across FT, in line with the study design, and reflective of the range within seasonal pasturebased production environments, from generous feeding to a slight under feeding.

Considerable genetic gain via selection based on EBI is evident from national trends (ICBF, 2017). The favorable implication of EBI from a productivity perspective (yield of milk solids per cow) has been confirmed by O'Sullivan et al. (2019) and is in accordance with the daily production performance presented in the current study. Elite cows displayed a performance in line with selection goal: lower daily volumes of milk with significantly higher fat and protein content, conveying higher milk value. Expressed in energetic terms, however, daily milk production was similar. The component 
O'SULLIVAN ET AL.
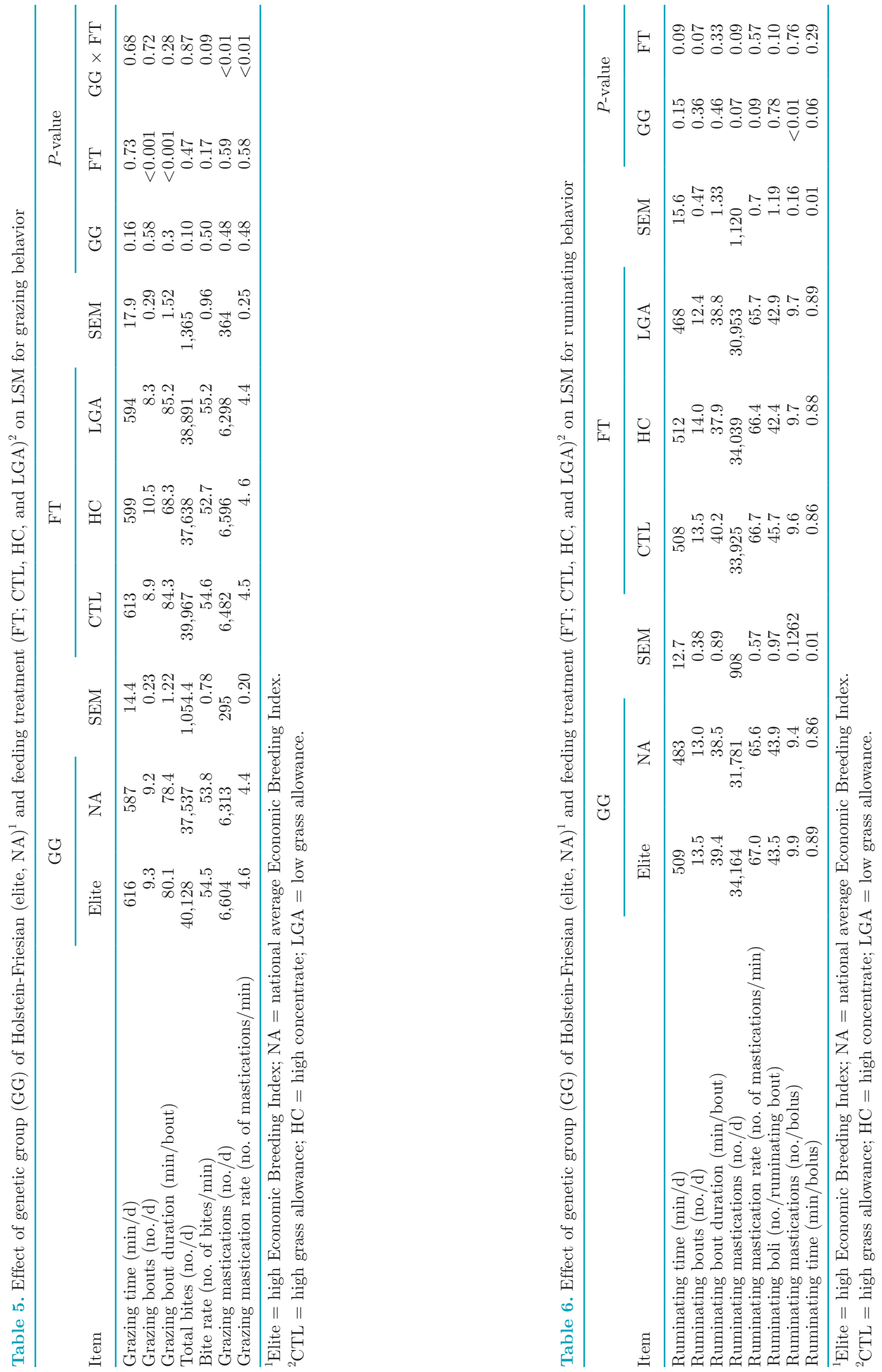
composition of milk from elite cows in the present study is greater than previous studies that have investigated the performance of HF cows across different pasturebased FT at this research center (Horan et al., 2006; McCarthy et al., 2007; Coleman et al., 2010; Coffey et al., 2017) and is reflective of genetic progress nationally (ICBF, 2017).

The lower BW of elite cows (Table 3) is consistent with their favorable maintenance sub-index compared with NA, and also consistent with the objective of breeding more moderately sized dairy cows requiring less energy for maintenance, whereby a negative economic weighting ( $-€ 1.65$ per $\mathrm{kg}$ carcass weight) is placed on cow size within the EBI (ICBF, 2017).

Sustainable genetic improvement is contingent on compatibility with the system in which the genetics is expected to perform. Dairy cows with the grazing aptitude to achieve high DMI of grazed pasture to meet their productive potential are integral to the success of pasture-based systems (Delaby et al., 2018). Limitations of grazing systems in terms of pasture productivity and utilization necessitate animals capable of achieving high conversion efficiency of available feed to milk solids to maximize productivity (Coffey et al., 2018). The findings of the current study indicate that DMI per se is not affected by EBI, despite the considerable difference in EBI represented. Previous studies have observed higher pasture DMI with cows selected intensively for MY (Kolver and Muller, 1998; Buckley et al., 2000; Kennedy et al., 2003; Horan et al., 2006) but generally an inability to consume sufficient pasture to meet their energy requirements from a predominantly pasture-based diet.

The elite cows in the present study achieved a significantly higher intake relative to their BW compared with NA, albeit a small absolute difference in practical terms. In a study comparing strains within HF, Coleman et al. (2010) reported higher TDMI/100 kg of BW $(3.17 \mathrm{~kg}$ of DM per $100 \mathrm{~kg}$ of BW) in a New Zealand strain of HF of lower BW on a high grass allowance feeding system compared with a medium genetic merit strain of North American HF (3.04 kg of DM per $100 \mathrm{~kg}$ of BW) and a high genetic merit strain of North American HF (2.99 kg of DM per $100 \mathrm{~kg}$ of BW). Relative to the levels observed in that study, the higher absolute level of intake per unit BW achieved by elite cows in the present study suggests genetic progress in terms of both production potential and consequent DMI potential in HF selected for high EBI. Mackle et al. (1996) demonstrated the greater ability of Jersey (JE) cows to achieve higher intake per unit of BW, compared with HF cows. Similarly, Prendiville et al. (2009) reported TDMI of $3.99 \mathrm{~kg}$ per $100 \mathrm{~kg}$ of BW in JE cows, and $3.63 \mathrm{~kg}$ per $100 \mathrm{~kg}$ of $\mathrm{BW}$ in $\mathrm{JE} \times \mathrm{HF}$ cows, compared with TDMI of $3.39 \mathrm{~kg}$ per $100 \mathrm{~kg}$ of BW reported for HF cows. Both Smith and Baldwin (1974) and Beecher et al. (2014) highlighted differences between JE and HF in gastrointestinal tract weight, rumen microbial population, and digestive ability as factors contributing to the greater efficiency of intake with JE. Notwithstanding these characteristic differences, the JE breed with its small size and large intake capacity represents the extreme in dairy type, and closely resembles the ideal cow for intensive grazing systems (Prendiville et al., 2010). Therefore, in absolute terms, while the observation in this regard is favorable, elite cows in the present study remain in HF territory relative to the JE breed in terms of DMI capacity. However, the trends observed suggest genetic progress for increased intake capacity in HF selected for high EBI and this is considered positive given the importance of intake capacity for grazing systems (Berry, 2015).

Substitution rate, the decrease of pasture DMI per kilogram of supplement DM, provides an indication of the degree to which energy requirements are met from pasture (Faverdin et al., 1991). Under-satiated animals experience a lower reduction in GDMI when supplemented with concentrate (Coulon and Rémond, 1991). The observed substitution rate for elite and NA in the present study indicates that a high level of the energy requirement of both GG in the present study is met from pasture, indicating a similar drive for energy intake in both GG, and comparable to the levels reported by Horan et al. (2006) and McCarthy et al. (2007) for high durability North American HF. In contrast, high production animals in the study of Horan et al. (2006) displayed low substitution rates throughout lactation $(0.24,0.16$, and $0.17 \mathrm{~kg}$ per $\mathrm{kg}$, in spring, summer, and autumn, respectively), indicating that the EB of these animals was appreciably improved by the inclusion of supplementary concentrate in the diet, highlighting their inability to consume sufficient herbage to meet their energetic requirements. An inability to meet energetic requirements from pasture would also likely confer a reduced likelihood of survival, an integral component of optimal financial performance (Lopez-Villalobos et al., 2000). By contrast, high merit HF of New Zealand origin in the study of Horan et al. (2006) displayed lower production potential, lower GDMI, and higher substitution rates than either GG in the present study. Cows in the present study, selected for high EBI, appear to maintain an inherent drive for feed intake to sustain high levels of production, even when supplemented with additional concentrate at pasture.

Grainger and Goddard (2004) highlighted that a greater proportion of the DMI of HF cows is allocated to maintenance requirements compared with JE and $\mathrm{JE} \times \mathrm{HF}$. This greater dilution of maintenance require- 
ments by both JE and JE $\times$ HF cows ultimately results in increased milk solids production per kilogram of DMI and per unit of BW. According to Prendiville et al. (2009), from a practical perspective, a key determinant of $\mathrm{PE}$ must be the $\mathrm{NE}_{\mathrm{I}}$ per unit of milk solids produced, or broadly reversed, the milk solids output per unit of intake. Given their numerically higher intake capacity, higher intake per $100 \mathrm{~kg}$ of BW, and greater milk solids output per $\mathrm{kg}$ of $\mathrm{BW}$, it may be expected that elite animals would display superior efficiency in the utilization of $\mathrm{NE}_{\mathrm{I}}$ for milk production compared with $\mathrm{NA}$, once energy requirements for maintenance are met. However, no difference in $\mathrm{NE}_{\mathrm{I}} / \mathrm{kg}$ of milk solids yield was observed. The tendency is actually toward a lower $\mathrm{NE}_{\mathrm{L}} / \mathrm{NE}_{\mathrm{I}}-\mathrm{NE}_{\mathrm{M}}$, indicating a slight inefficiency in the utilization of available energy for milk production with elite. This supports the findings of O'Sullivan et al. (2019), whose analysis suggested no evident improvement in the efficiency of feed utilization in elite cows. Partitioning more ME to milk production and less to body reserves will improve food conversion efficiency in the short term. In the long term, however, it will not be sustainable and is associated with reduced animal health and fertility (Butler and Smith, 1989). The higher intake capacity of the elite cows in conjunction with a similar $\mathrm{NE}_{\mathrm{L}}$ and lower $\mathrm{BW}$ manifests a more favorable EB, which was substantiated by a clear propensity by elite cows to maintain a higher BCS. This is likely to enhance robustness, increase productive longevity, and increase lifetime efficiency (Friggens et al., 2017).

Previous studies have documented the nuanced mechanisms governing pasture intake among various dairy genotypes (Linnane et al., 2004; Prendiville et al., 2010). Broadly, as expected, the manner in which pasture intake was manifested by both elite and NA cows in the present study was similar. Noteworthy was a consistent numerical trend toward more intense grazing and ruminating activity with elite compared with NA cows. This is likely associated with a slightly reduced physical size (as evidenced by weight) in combination with an inherent drive to sustain high productivity, in line with that published by Laborde et al. (1998). The intensity of behavior is emphasized by the fact that both total grazing time and total bites per day breached the suggested ceiling proposed by Stobbs (1973). The FT trends reflective of increased energy density $(\mathrm{HC})$ and restricted grass allowance (LGA) are broadly in line with expectations based on previous comparable findings (O'Connell et al., 2000; Linnane et al., 2004). However, although concentrate supplementation changed the pattern of grazing, it did not affect total grazing time or biting rate. Therefore, both the grazing behavior and substitution rate observed reflect a high drive for pasture intake and are a function of the potential for high productivity from pasture of both genotypes in the current study. Lower bite rates, higher number of grazing bouts, and lower rumination times of New Zealand HF cows on a high concentrate feeding system in the study of Linnane et al. (2004) suggest that the grazing appetite of that strain of HF was compromised by the provision of supplementary concentrate. A repeat study by McCarthy et al. (2007) found a similar result; New Zealand HF cows had lower grass DMI and higher substitution rates compared with 2 other strains. In contrast, the animals in the present study, selected for high EBI, appear to maintain an inherent drive for feed intake to maintain high levels of production even when supplemented with additional concentrate at pasture. These findings affirm the compatibility of cows selected on EBI for production in grazing environments.

\section{CONCLUSIONS}

The present study highlights the sustainability of selection using EBI in terms of the compatibility of the resultant genetics with grazing across a range of grazing management scenarios. Ultimately, elite genetics represent an advancement of the philosophies of authors such as Buckley et al. (2000), Kennedy et al. (2003), and Horan et al. (2006) on the selection of appropriate genetics for pasture-based systems, combining production potential for high value milk solids, high DMI capacity, strong inherent grazing aptitude, positive EB, and the ability to maintain high BCS. It is clear that the favorable characteristics observed with elite cows approach the ideal for grazing, and are borne out of genetic improvement based on balanced selection for traits of economic importance to pasturebased systems of milk production. The findings provide evidence of a slight reduction in the utilization of ingested energy for milk production, but this is likely to enhance robustness, increase productive longevity, and increase lifetime efficiency. However, further research is warranted to validate this point.

\section{ACKNOWLEDGMENTS}

The technical assistance of Ricki Fitzgerald and the diligent work of the farm staff at the Dairygold Research Farm (Teagasc, Animal and Grassland Research and Innovation Centre, Moorepark, Fermoy, Co. Cork, Ireland) are gratefully acknowledged. The technical expertise provided by Michael O'Donovan of Teagasc Moorepark is gratefully acknowledged. The authors acknowledge the financial support of the Irish Department of Agriculture Food and the Marine Research Stimulus Fund 13/S/496 RAPIDFEED. 


\section{REFERENCES}

Bargo, F., L. D. Muller, E. S. Kolver, and J. E. Delahoy. 2003. Invited review: Production and digestion of supplemented dairy cows on pasture. J. Dairy Sci. 86:1-42.

Beecher, M., F. Buckley, S. M. Waters, T. M. Boland, D. EnriquezHidalgo, M. H. Deighton, M. O'Donovan, and E. Lewis. 2014. Gastrointestinal tract size, total-tract digestibility, and rumen microflora in different dairy cow genotypes. J. Dairy Sci. 97:3906-3917.

Berry, D. P., and J. Crowley. 2013. Cell Biology Symposium: Genetics of feed efficiency in dairy and beef cattle. J. Anim. Sci. 91:15941613.

Berry, D. P. 2015. Breeding the dairy cow of the future: What do we need? Anim. Prod. Sci. 55:823-837.

Buckley, F. 1998. Effect of genotype of cow and system of feeding on milk production, feed intake and nutrient utilisation of springcalving Holstein-Friesian dairy cows in Ireland. PhD Thesis. Department of Animal Science and Production, University College Dublin, Ireland.

Buckley, F., P. Dillon, M. Rath, and R. F. Veerkamp. 2000. The relationship between genetic merit for yield and live weight, condition score, and energy balance of spring calving Holstein Friesian dairy cows on grass based systems of milk production. J. Dairy Sci. 83:1878-1886.

Buckley, F., C. Holmes, and M. G. Keane. 2005. Genetic characteristics required in dairy and beef cattle for temperate grazing systems. Utilisation of grazed grass in temperate animal systems. J. H. Murphy, ed. Pages 61-79 in Proceeding of a Satellite Workshop of the XXth International Grassland Congress. Wageningen Academic Publishers, Wageningen, the Netherlands.

Butler, W. R., and R. Smith. 1989. Interrelationships between energy balance and postpartum reproductive function in dairy cattle. J. Dairy Sci. 72:767-783.

Chapa, A. M., J. M. Fernandez, D. L. Thompson Jr., R. J. Tempelman, L. F. Berrio, W. J. Croom Jr., and W. M. Hagler Jr.. 1995. Endocrine and metabolic response to muscarinic stimulation and inhibition in the ruminant: Effects of slaframine. J. Anim. Sci. 73:3673-3680.

Coffey, E. L., L. Delaby, S. Fitzgerald, N. Galvin, K. M. Pierce, and B. Horan. 2017. Effect of stocking rate and animal genotype on dry matter intake, milk production, body weight, and body condition score in spring-calving, grass-fed dairy cows. J. Dairy Sci. 100:7556-7568.

Coffey, E. L., L. Delaby, C. Fleming, K. M. Pierce, and B. Horan. 2018. Multi-year evaluation of stocking rate and animal genotype on milk production per hectare within intensive pasture-based production systems. J. Dairy Sci. 101:2448-2462.

Coleman, J., K. M. Pierce, D. P. Berry, A. Brennan, and B. Horan. 2010. Dry matter intake and feed efficiency profiles of 3 genotypes of Holstein-Friesian within pasture-based systems of milk production. J. Dairy Sci. 93:4318-4331.

Coulon, J., and B. Rémond. 1991. Variations in milk output and milk protein content in response to the level of energy supply to the dairy cow: A review. Livest. Prod. Sci. 29:31-47.

Delaby, L., F. Buckley, N. McHugh, and F. Blanc. 2018. Robust animals for grass based production systems. Sustainable meat and milk production from grasslands. Pages 389-400 in Proc. 27th General Meeting of the European Grassland Federation, Cork, Ireland, 17 June-21 June, 2018. European Grassland Federation EGF, Zürich, Switzerland.

Dillon, P., and G. Stakelum. 1989. Herbage and dosed alkanes as a grass measurement technique for dairy cows. Ir. J. Agric. Sci. Res. $28: 104$.

Dohme-Meier, F., L. D. Kaufmann, S. Görs, P. Junghans, C. C. Metges, H. A. Van Dorland, R. M. Bruckmaier, and A. Münger. 2014. Comparison of energy expenditure, eating pattern and physical activity of grazing and zero-grazing dairy cows at different time points during lactation. Livest. Sci. 162:86-96.

Evans, R. D., P. Dillon, F. Buckley, D. P. Berry, M. Wallace, V. Ducrocq, and D. J. Garrick. 2006. Trends in milk production, calving rate and survival of cows in 14 Irish dairy herds as a result of the introgression of Holstein-Friesian genes. Anim. Sci. 82:423-433.

Faverdin, P., J. P. Dulphy, J. B. Coulon, R. Vérité, J. P. Garel, J. Rouel, and B. Marquis. 1991. Substitution of roughage by concentrates for dairy cows. Livest. Prod. Sci. 27:137-156.

Friggens, N. C., F. Blanc, D. Berry, and L. Puillet. 2017. Deciphering animal robustness. A synthesis to facilitate its use in livestock breeding and management. Animal 11:2237-2251.

Grainger, C., and M. E. Goddard. 2004. A review of the effects of dairy breed on feed conversion efficiency - An opportunity lost? Pages 77-80 in Animal Production in Australia: Proc. 25th Biennial Conf. Aust. Soc. Anim. Prod., University of Melbourne, Victoria. Commonw. Sci. Ind. Res. Org., Victoria, Australia.

Hanrahan, L., N. McHugh, T. Hennessy, B. Moran, R. Kearney, M. Wallace, and L. Shalloo. 2018. Factors associated with profitability in pasture-based systems of milk production. J. Dairy Sci. 101:5474-5485.

Horan, B., P. Faverdin, L. Delaby, M. Rath, and P. Dillon. 2006. The effect of strain of Holstein-Friesian dairy cow and pasture-based system on grass intake and milk production. Anim. Sci. 82:435444

ICBF. 2017. Irish Cattle Breeding Federation. Update to Economic Values in the EBI. Accessed Jan. 20, 2018. https://www.icbf.com/ $\mathrm{wp} / \mathrm{?}=9695$.

Jarrige, R. 1989. Ruminant Nutrition: Recommended Allowances and Feed Tables. INRA, Paris, France. Accessed Nov. 10, 2018. https:/ /books.google.fr/books?id=fgW8pVo6T-UC.

Kennedy, J., P. Dillon, L. Delaby, P. Faverdin, G. Stakelum, and M. Rath. 2003. Effect of genetic merit and concentrate supplementation on grass intake and milk production with Holstein Friesian dairy cows. J. Dairy Sci. 86:610-621.

Kolver, E. S., and L. Muller. 1998. Performance and nutrient intake of high producing Holstein cows consuming pasture or a total mixed ration. J. Dairy Sci. 81:1403-1411.

Laborde, D., D. G. Garcia-Muniz, and C. W. Colmes. 1998. Herbage intake, grazing behavior and feed conversion of lactating HolsteinFriesian cows that differ genetically for body weight. Proc. N.Z. Soc. Anim. Prod. 58:128-131.

Linnane, M., B. Horan, J. Connolly, P. O'Connor, F. Buckley, and P. Dillon. 2004. The effect of strain of Holstein-Friesian and feeding system on grazing behaviour, herbage intake and productivity in the first lactation. Anim. Sci. 78:169-178.

Lopez-Villalobos, N., D. J. Garrick, H. T. Blair, and C. W. Homes. 2000. Possible effects of 25 years of selection and crossbreeding on the genetic merit and productivity of New Zealand dairy cattle. J. Dairy Sci. 83:154-163.

Lowman, B. G., N. Scott, and S. Somerville. 1976. Condition scoring of cattle. Bull. of the East Scotland College of Agriculture. No. 6. Rev. ed. East of Scotland College of Agriculture, Edinburgh, UK.

Mackle, T., C. Parr, G. Stakelum, A. Bryant, and K. Macmillan. 1996. Feed conversion efficiency, daily pasture intake, and milk production of primiparous Friesian and Jersey cows calved at two different liveweights. N. Z. J. Agric. Res. 39:357-370.

Manzanilla-Pech, C. I. V., R. F. Veerkamp, Y. de Haas, M. P. L. Calus, and J. ten Napel. 2017. Accuracies of breeding values for dry matter intake using nongenotyped animals and predictor traits in different lactations. J. Dairy Sci. 100:9103-9114.

Mayes, R. W., C. S. Lamb, and P. M. Colgrove. 1986. The use of dosed and herbage n-alkanes as markers for the determination of herbage intake. J. Agric. Sci. (Camb.) 107:161-170.

McCarthy, S., B. Horan, M. Rath, M. Linnane, P. O'Connor, and P. Dillon. 2007. The influence of strain of Holstein-Friesian dairy cow and pasture-based feeding system on grazing behaviour, intake and milk production. Grass Forage Sci. 62:13-26.

Miglior, F., J. Chesnais, and B. Van Doormaal. 2012. Genetic improvement: A major component of increased dairy farm profitability. Invited Presentation at 38th ICAR Biennial Session held in Cork, Ireland. ICAR Technical Series. International Committee for Animal Recording, Rome, Italy. 
Miglior, F., A. Fleming, F. Malchiodi, L. F. Brito, P. Martin, and C. F. Baes. 2017. A 100-Year Review: Identification and genetic selection of economically important traits in dairy cattle. J. Dairy Sci. 100:10251-10271.

Morgan, D., G. Stakelum, and J. Dwyer. 1989. Modified neutral detergent cellulase digestibility procedure for use with the 'Fibertec' system. Isr. J. Agric. Res. 28:91-92.

Ngwerume, F., and I. Mao. 1992. Estimation of residual energy intake for lactating cows using an animal model. J. Dairy Sci. 75:22832287.

O'Connell, J., F. Buckley, M. Rath, and P. Dillon. 2000. The effects of cow genetic merit and feeding treatment on milk production, herbage intake and grazing behaviour of dairy cows. Ir. J. Agric. Food Res. 39:369-381.

O'Donovan, M., E. Lewis, and P. O'Kiely. 2011. Requirements of future grass-based ruminant production systems in Ireland. Ir. J. Agric. Food Res. 50:1-21.

O'Mara, F. 2000. A Net Energy System for Cattle and Sheep. Version 1.2. Univ. Coll. Dublin, Ireland.

O'Sullivan, M., B. Horan, K. M. Pierce, S. McParland, K. O'Sullivan, and F. Buckley. 2019. Milk production of Holstein-Friesian cows of divergent Economic Breeding Index evaluated under seasonal pasture-based management. J. Dairy Sci. https://doi.org/10.3168/ jds.2018-15559. In press.

Prendiville, R., E. Lewis, K. M. Pierce, and F. Buckley. 2009. An evaluation of production efficiencies among lactating HolsteinFriesian, Jersey, and Jersey x Holstein-Friesian cows at pasture. J. Dairy Sci. 92:6176-6185.

Prendiville, R., E. Lewis, K. M. Pierce, and F. Buckley. 2010. Comparative grazing behavior of lactating Holstein-Friesian, Jersey, and Jersey $\times$ Holstein-Friesian dairy cows and its association with intake capacity and production efficiency. J. Dairy Sci. 93:764-774.

Pryce, J. E., O. Gonzalez-Recio, G. Nieuwhof, W. J. Wales, M. P. Coffey, B. J. Hayes, and M. E. Goddard. 2015. Hot topic: Definition and implementation of a breeding value for feed efficiency in dairy cows. J. Dairy Sci. 98:7340-7350.

SAS Institute Inc. 2017. User's Guide: Statistics. Version 9.4. SAS Institute Inc., Cary, NC.

Shalloo, L., P. Dillon, M. Rath, and M. Wallace. 2004. Description and validation of the Moorepark Dairy System Model. J. Dairy Sci. 87:1945-1959.

Smith, N., and R. Baldwin. 1974. Effects of breed, pregnancy, and lactation on weight of organs and tissues in dairy cattle. J. Dairy Sci. 57:1055-1060.

Steinfeld, H., and J. Mäki-Hokkonen. 1995. A classification of livestock production systems. Wld. Anim. Rev. 83-94.

Stobbs, T. 1973. The effect of plant structure on the intake of tropica pastures. I. Variation in the bite size of grazing cattle. Aust. J. Agric. Res. 24:809-819.

Van Soest, P. J., J. B. Robertson, and B. A. Lewis. 1991. Methods for dietary fiber, and nonstarch polysaccharides in relation to animal nutrition. J. Dairy Sci. 74:3583-3597.

Van Vuuren, A. M., and A. Van den Pol-van Dasselaar. 2006. Grazing systems and feed supplementation. Pages 85-101 in Fresh Herbage for Dairy Cattle. A. Elgersma, J. Dijkstra, and S. Tamminga, ed. Springer, Wageningen, the Netherlands.

Veerkamp, R. F., P. Dillon, E. Kelly, A. R. Cromie, and A. F. Groen. 2002. Dairy cattle breeding objectives combining yield, survival and calving interval for pasture-based systems in Ireland under different milk quota scenarios. Livest. Prod. Sci. 76:137-151.

Washburn, S. P., and K. A. E. Mullen. 2014. Invited review: Genetic considerations for various pasture-based dairy systems. J. Dairy Sci. 97:5923-5938.

Werner, J., L. Leso, C. Umstatter, J. Niederhauser, E. Kennedy, A. Geoghegan, L. Shalloo, M. Schick, and B. O'Brien. 2018. Evaluation of the RumiWatchSystem for measuring grazing behaviour of cows. J. Neurosci. Methods 300:138-146. 